\title{
The Competence of the Learners of Rural Vernacular Medium Government Schools and Urban English Medium Private Schools in Acquiring Paragraph Writing Skill in English in the Select Schools of Tiruchirappalli District: An Action Research
}

\author{
Dr. S. Joseph Arul Jayraj \\ Associate Professor of English, St. Joseph's College (Autonomous), Tiruchirappalli-620 002, Tamil Nadu, South India.
}

\begin{abstract}
This paper is written based on an action research conducted to test the competence of the learners of Vernacular Medium Schools and the learners of English Medium Schools in acquiring paragraph writing skill. The objectives of the paper are enlisted, 'action research' is defined, and the need for the study is mentioned and the hypothesis is framed. 'Diagnostic test' is defined, the need to conduct it, the importance of framing objectives to conduct it, the objectives and logic behind devising and administering it are presented. The demographics of Manikandam and Andanallur Blocks, selection of the learner sample, time spent to select the schools to administer the Diagnostic test, the procedure adopted in evaluating the Diagnostic test, the components of evaluation and the efforts taken to ensure the quality of the Diagnostic test and assessment are explained. The procedure adopted to escape from the experimenter's bias and testing bias is described. The analysis and interpretation of the data collected, comments of the evaluators and verification of the hypothesis and the discussion of the findings are rendered. The paper is logically concluded with the sources of references.

Keywords: action research, communicative competence, diagnostic test, proficiency test, aptitude test, text and accuracy, experimenter-bias, demographics, operational efficiency, etc.
\end{abstract}

\section{The Need to Frame Objectives}

Framing objectives is the most important step before conducting any test. Each objective displays its own general and specific characteristic behaviour and therefore it clearly communicates the aims and objectives of conducting the Diagnostic test.

An investigator is supposed to know exactly what and how he/she is going to test and what the learners have to do. Besides the broad and general aims, the investigator should have specific or particular objectives for testing the writing skills of the learners in English as a second language. If the investigator can visualize it clearly, then testing the writing skills of the learners in English becomes easy and fruitful. It solves the problems of the investigator such as what skill he/she should test in the learners, which method or approach he/she should adopt etc. Without the knowledge of the aims and objectives, one will be groping about in darkness. These problems can be solved only when the aims and objectives of testing the writing skills of the learners have been fixed in the beginning. Therefore, it is highly desirable to have very specific objectives because they give focus, concentration and progress to the work undertaken.

\section{Objectives of this Paper}

a. To make the readers understand and aware of the status of ELT in rural Vernacular medium government schools and in urban English medium private schools.

b. To make the readers think aloud in this area chosen for research.

c. To enable the readers to raise certain questions and to exhort the readers to carry out an in-depth research in this area, so that they would be able to find solutions or propose strategy to rectify the prevailing scenario and to teach English effectively in rural Vernacular medium government schools.

\section{Introduction}

An experimental study is a scientific, practical, reliable and useful procedure for description and analysis of the outcome of the experiment carried out by monitoring the assigned tasks to groups of learners.

While the concept of action research can be traced back to the early works of John Dewey in the 1920s and Kurt Lewin in the 1940s, it is Stephen Corey and others at Teachers College of Columbia University who introduced the term action research to the educational community in 1949. Corey (1953) defined action research as the process through which practitioners study their own practice to solve their personal practical problems. (Beverly par. 3[1]) 


\section{The Need For The Study}

In the present academic arena in schools, proper and effective training in writing accurately in English is given scant attention but the need to express one's ideas accurately in written communication in English is increasing day by day. Even after learning English as a second language for twelve years at schools, where the medium of instruction is the vernacular, the learners find it difficult to acquire it. One can observe that most of the students, who write answers in English in the examinations, manage to memorize them and reproduce them in the examination. The learners hardly take any useful effort to acquire writing skills in English accurately. In the Schools, Colleges and Universities in India, the learners are trained and evaluated in writing in English. If the writing skills are not acquired well at the School level, the learners will lack efficiency in written communication at the consecutive levels of their education. The popular ritual of teaching English as a second language through the vernacular has proved itself to be not useful in acquiring the writing skills in English. Therefore, not only the teachers of English in the schools but also the investigator confined themselves to test only the writing skills of the learners because of the compulsions of the pattern of the question paper in the examinations that writing in English has come to a stay as a popular mode of communication.

Language testing is one of the most difficult tasks for the teachers. The real problem in testing the competence of the learners in writing in English is that there is no single, tried and fool-proof method to do it. If anyone claims that there is the best method in vogue, one can be sure of the fact that he is speaking outside his knowledge and competence. Moreover, such a claim will be nothing short of a tall claim.

The learners' written communication in the examination at collegiate level in India is very poor. It shows the fact that the learners are not trained properly to express their ideas through writing. This study originated from the above-said awareness of the importance of acquiring writing skills in English and from the need for the effective use of them among the learners at the school level.

\section{Hypothesis Framed}

The writing skills of the learners of English Medium Schools are likely to be better than that of the learners of Vernacular Medium Schools.

\section{A Note On The Diagnostic Test}

Diagnostic Test is defined as "an intensive, in-depth evaluation process with a relatively detailed and narrow coverage of a specific area. The purpose of this test is to determine the specific learning needs of individual students and to be able to meet those needs through regular or remedial classroom instruction" (http://ericae.net/edo/ed 315430. htm [2]).

\section{The Need To Conduct The Diagnostic Test}

a. Diagnostic test is essential to identify the age, standard, background, interests and needs of the learners. So, this should be the first step in conducting any action research.

b. Unlike the Revision tests, which are Achievement tests in nature, the Diagnostic test is not tied to a syllabus or a set of materials.

c. The Proficiency test at the entry level is one, which tests the competencies of learners required to do things in the target language.

d. Like an Aptitude test, the Diagnostic test is meant to measure the learners' special skills for acquiring English as a Second language.

e. The standard of the performance of the learners in the Diagnostic test is judged by the difference among the scores of the learners.

f. The Diagnostic test was administered by the investigator to test the abilities of the learners to write in English accurately.

\section{The Objectives And Logic Behind Devising The Diagnostic Test Are}

1. To test the knowledge and the writing skills of the learners in English.

2. To know the standard of the learners in English.

3. To devise a suitable method of teaching English.

4. To bring the learners up to the basic standard that is needed to enable them to acquire writing skills in English.

\section{The Objectives Of Administering The Diagnostic Test}

a. To know the ability of the learners to construct grammatically correct sentences in English.

b. To identify the factors that are responsible for not allowing the learners to learn English accurately. 


\section{Time}

The Diagnostic test was administered on $6^{\text {th }}$ July 2014 to the English Medium Learners and on $28^{\text {th }}$ and $31^{\text {st }}$ July 2014 for the Vernacular Medium Learners. The total time given to the learners to write a paragraph in English on the topic "My School" was 10 minutes.

\section{Selection Of Schools To Administer The Diagnostic Test}

The schools were selected at random by the investigator. The Diagnostic test was administered to the students of the four select English medium schools and to the learners of four select Vernacular medium schools in order to know the ability of the learners to express themselves in English accurately.

\section{1, Experimenter's Bias}

\section{Evaluation Of The Diagnostic Test}

By allowing two of his colleagues to evaluate the Diagnostic test performance of the learners, the investigator was totally objective in generalizing the validity of his experiment and he guarded himself against the experimenter-bias.

\section{2, Testing Bias}

In order to test the linguistic competencies of the learners in the Diagnostic test objectively, the investigator requested two of his colleagues Dr. J. John Love Joy and Mr. M. John Britto, Assistant Professors of English, St. Joseph's College (Autonomous), Tiruchirappalli-620002, to evaluate the Diagnostic test scripts and present the statement of marks. Thus, the investigator evaded an element of bias in testing the writing competencies of the learners.

\section{Components Of Evaluation}

Text refers to the content, which is communicated in the form of concept and meaning. ... "Accuracy refers to the ability to produce grammatically correct sentences, but may not include the ability to speak or write fluently. Its over-use may impede language development" (Methods of Teaching English, Block II, 61- 62 [3]). Accuracy-based language activity is also necessary especially at the early stage of language learning because in such a situation it helps to reinforce certain language forms through repetition. "Communicative competence is the ability to show not only linguistic or grammatical competence but also rules of use, when and where to use language appropriately" (61). So, accuracy-based language activities should not be ignored in any language teaching and evaluation programme.

In the Diagnostic test, the activity of writing a paragraph on "My School" was evaluated under the following two categories. They are: Text and Accuracy [emphasis added]. This activity, consisting of two components, was evaluated for twenty marks. Each component carried ten marks. It is justified by Keith Johnson that ... accuracy-based language activities " ... can only be practised in a language teaching which is task-oriented" (Methods of Teaching English Block II, 46 [3]).

\section{Efforts That Have Been Taken To Ensure The Quality Of Thediagnostic Test And Assessment Are}

a. The Diagnostic test was administered to four students of four different Private English Medium Schools namely Alpha Plus Matriculation School, St. Antony's Matriculation School, Orchard Matriculation School and SBIOA Matriculation School, which are located in different parts of Tiruchirappalli town.

b. The Diagnostic was administered to four students of four different Government Schools namely Government High Secondary School, Keerikkalmedu, which is located in Andanallur Block, Tiruchirappalli district; Government Higher Secondary School, Poongudi, Government Higher Secondary School, Inam Mathur and Government Higher Secondary School, Somarasanpettai, which are located in different parts of Manikandam Block, Tiruchirappalli district. These four select schools are located $14 \mathrm{~km}$ away from Tiruchirappalli town.

c. The students cooperated with the investigator and showed a lot of enthusiasm and interest in writing the Diagnostic test.

\section{Demographics Of Manikandam And Andanallur Blocks}

The native language of Manikandam Block and Andanallur Block is Tamil and most of the people use Tamil for communication. 


\section{Procedure Adopted In Conducting The Diagnostic Test In Schools \\ 14.1, Selection of the Learner Sample}

The investigator approached the authorities of various English Medium School which are established in Tiruchirappalli town in order to get permission to conduct the investigation. But it was denied to him for the reason that the standard of the schools will be made known to the public authentically and it will drastically diminish the number of students who come for admission and spoil the name and income of the schools. Therefore, the investigator chose the students who lived in the neighbourhood but studied in various schools. He got the permission of the parents of the students to conduct the investigation.

When the investigator approached the teachers of the Government Schools in Manikandam Block which is supposed to be the most backward area of Tiruchirappalli district in economic, social, financial and educational realms, they cooperated with the investigator willingly by selecting and sending the learners of their choice to write the Diagnostic test. The sample group of learners given to the investigator by the teachers from the Vernacular Medium Schools was a heterogeneous one. But the sample group of students chosen by the investigator himself from the English Medium Schools was a homogeneous one. The students were both boys and girls of eight in number. The common factors that united them were:

i) Four learners each who belonged to the Vernacular Medium Schools where English is taught only as a Second language.

ii) The other four learners each who belonged to the English Medium Schools where English is taught as the First language.

iii) The differences found in the performance of individuals are not owing to the result of their academic competencies alone. Much depends on their social, psychological and economic background. However, special remedial measures can be carried out to remove the heterogeneity that is likely to exist among the learners.

\section{2, Procedure Adopted in Administering the Diagnostic Test to a Single Group of Learners from Different Schools}

After knowing the profile of the test-takers, the investigator asked the students to write a paragraph in English on the topic "My School" and administered a test to a group of six students who belong to different classes and schools. The Diagnostic test was conducted at the investigator's house only in the written mode in English because administering written test is in vogue not only a popular mode of testing in all schools but also the only mode of testing practised in all schools. Moreover, it is also a familiar mode of testing the learners and it can also be counted as a verifiable proof of the learners' language proficiency in English.

\section{Methods Of Evaluation}

The answer scripts of the Diagnostic test performance of the learners were presented for evaluation to two Assistant Professors of English, St. Joseph's College (Autonomous), Tiruchirappalli. The Diagnostic test performance of the learners was evaluated in terms of Text and Accuracy [emphasis added]. As it was justified by Keith Johnson that fluency and accuracy-based language activities "...could only be practised in a language teaching which was task-oriented" (Methods of Teaching English, 46 [3]). Under each component of evaluation, the performance of the learners was evaluated for ten marks. Thus, the components of evaluation used by the examiners in rating the Diagnostic test performance of the learners helped the examiners verify whether the learners had really understood the concept and meaning of the language activity tested and evaluate how far the learners had expressed their ideas accurately in English.

\section{Comments Of The Evaluators}

Dr. J. John Love Joy and Mr. M. John Britto have commented on the performance of the students as follows:

\begin{tabular}{|c|l|l|}
\hline $\begin{array}{c}\text { S. } \\
\text { No. }\end{array}$ & \multicolumn{1}{c|}{$\begin{array}{c}\text { Government Schools which have the Vernacular as the } \\
\text { Medium of Instruction }\end{array}$} & \multicolumn{1}{c|}{$\begin{array}{c}\text { Private Schools which have English as the Medium of } \\
\text { Instruction }\end{array}$} \\
\hline 1 & $\begin{array}{l}\text { The overall performance of the learners concerning the } \\
\text { English language skills in the Diagnostic test is not good. } \\
\text { Accuracy, which is a mark of confidence, is not perceptible } \\
\text { from their performance. }\end{array}$ & $\begin{array}{l}\text { The overall performance of the learners concerning the English } \\
\text { language skills in the Diagnostic test is fair. Accuracy, which is a } \\
\text { mark of confidence, is perceptible from their performance. }\end{array}$ \\
\hline 2 & $\begin{array}{l}\text { Some learners need to learn basic grammatical structures and } \\
\text { sentence patterns of English and should learn how to use } \\
\text { them. }\end{array}$ & $\begin{array}{l}\text { Some learners need to learn to differentiate between 'small' and } \\
\text { capital' letters and should learn when to use them. Some } \\
\text { learners start the names of persons with small letter. }\end{array}$ \\
\hline 3 & $\begin{array}{l}\text { Many learners are unable to use the third person subject } \\
\text { followed by the correct verb form for the sentences with } \\
\text { third person subject. }\end{array}$ & $\begin{array}{l}\text { Many learners have the difficulty with regard to possessive } \\
\text { pronouns. Some are unable to use the expression like "one of } \\
\text { the...", etc correctly, while one or two have errors concerning the } \\
\text { third person subject followed by the correct verb. }\end{array}$ \\
\hline 4 & $\begin{array}{l}\text { Rigorous training, with a special focus on those words/ } \\
\text { phrases or sentence structures which are written wrongly, } \\
\text { would certainly make the learners correct their errors in } \\
\text { writing skills in English, and would help them to write more } \\
\text { accurately without mistakes. }\end{array}$ & $\begin{array}{l}\text { A little more training, with a special focus on those words/ } \\
\text { phrases or sentence structures which are written wrongly, would } \\
\text { certainly make the learners correct their errors in writing skills in } \\
\text { English, and would help them to write more accurately without } \\
\text { mistakes. }\end{array}$ \\
\hline
\end{tabular}




\section{The Need For Analysis And Interpretation Of The Data}

a. In any research, it is essential to collect the appropriate data through a scientific method in order to classify, tabulate and analyse them. They are also essential to draw useful inferences and conclusions.

b. Research may be defined as "the systematic and objective analysis and recording of controlled observation that may lead to the development of generalizations, principles, or theories, resulting in prediction and ultimate control of many events that may be consequences or causes of specific activities" (Best et al as qtd. in Ambedkar 60 [4]).

c. For the successful conduct of any research, suitable methodology with specific operational steps and wellconstructed tools is necessary. The success of the work depends on the appropriate selection of method and systematic procedure.

d. The investigator analysed the data collected from the Diagnostic test score of the selected group of learners to find out the effectiveness of their writing skills in English.

\section{Verification Of Hypothesis}

The performance of the learners of the English Medium Schools is likely to be better than that of the learners of the Vernacular Medium Schools. The results of the study show that this statement is true [emphasis added].

\section{Discussion Of The Findings}

The scores of the students of the Government Schools which have the Vernacular as the Medium of Instruction differ from that of the learners of the Private Schools which have English as the Medium of Instruction by a vast margin, which is not a negligible one. The difference in marks scored explains this fact. In connection with the Diagnostic test scores in the written mode, the four select schools in the Vernacular Medium are arranged in the order of descending levels of standard and also of descending levels of consistency as follows:

i) Government Higher Secondary School, Poongudi

ii) Government Higher Secondary School, Somarasanpettai,

iii) Government Higher Secondary School, Inam Mathur. All these three schools are situated in Manikandam Block and

iv) Government High School, Keerikkalmedu is situated in Andanallur Block.

Similarly, based on the Diagnostic test scores in the written mode, the four select schools in the English Medium are arranged in the order of descending levels of standard and also of descending levels of consistency as follows:

i) St. Antony's Matriculation School,

ii) SBIOA Matriculation School,

iii) Orchard Matriculation School, and

iv) Alpha Plus Matriculation School. All these schools are situated in Tiruchirappalli town.

The above-said results of the Diagnostic test confirm the fact that all learners of the eight select schools are intellectually very different from others, as there is vast difference between the scores of the learners of the Government Schools, which have the Vernacular as the Medium of Instruction and the scores of the learners of the Private Schools which have English as the Medium of Instruction. Unless this major difference is tackled properly at the early stage of their education, it may grow and emerge into a vast difference at the consecutive levels of education.

Hence, it is clear that the abilities and talents are present in the learners of the Government Schools which have the Vernacular as the Medium of Instruction. But they lie dormant. Their light is kept under the bushel (Matthew 5:15 [5]). It is the lack of opportunities, lack of intensive training, lack of quality education and lack of motivation that matter for the differences in their Diagnostic test scores.

Therefore, the test scores are the convincing empirical evidences which reveal the fact that learners do differ in their innate abilities to perform the language activities in English and there is also a lot of difference as to how they perform these language activities. If ample opportunities, guidance, sufficient motivation and continuous practice or drill are given, the learners of the Government Schools which have the Vernacular as the Medium of Instruction can do the language task as effectively as any learner of the Private Schools which have English as the Medium of Instruction. The growth in the intellectual abilities of the learners depends on the opportunities that they get to exercise their intellectual abilities, the facilities provided and the demands made by the social, economic and environmental factors in which they live.

Though the learners of the Government Schools which have the Vernacular as the Medium of Instruction can fare well as the learners of the Private Schools which have English as the Medium of Instruction, they do not. The following could be the reasons: 


\begin{tabular}{|c|c|c|}
\hline Points & $\begin{array}{l}\text { Private Schools which have English as the Medium of } \\
\text { Instruction }\end{array}$ & $\begin{array}{c}\text { Government Schools which have the Vernacular as the } \\
\text { Medium of Instruction }\end{array}$ \\
\hline 1 & $\begin{array}{l}\text { At least, a good number of learners have educated parents. So, } \\
\text { there is a good motivation at home to learn English accurately. }\end{array}$ & $\begin{array}{l}\text { Most of the learners have indifferent parents. Indifference } \\
\text { among the parents is a common phenomenon owing to } \\
\text { illiteracy. So, the illiterate parents are unable to motivate } \\
\text { their children at home to learn English accurately. }\end{array}$ \\
\hline 2 & $\begin{array}{l}\text { A good number of parents of the Private School learners are } \\
\text { interested in giving quality education to their children. They are } \\
\text { in a better social, economic and educational position. So, they } \\
\text { can afford to offer either coaching at home or private tuition to } \\
\text { their children. }\end{array}$ & $\begin{array}{l}\text { Most of the parents of Government School learners are not } \\
\text { in a position to offer quality education to their children } \\
\text { because of their low social, economic and educational } \\
\text { status. So, they cannot afford to offer either coaching at } \\
\text { home or private tuition to their children. }\end{array}$ \\
\hline 3 & $\begin{array}{l}\text { The teachers are accountable to the Management and the } \\
\text { Management is accountable to parents. So, teachers take efforts } \\
\text { to teach English well. }\end{array}$ & $\begin{array}{l}\text { The teachers do not teach English effectively because they } \\
\text { lack accountability and have indifferent attitude. The poor } \\
\text { standard of the learners in the Diagnostic test is the } \\
\text { evidence to prove this statement. }\end{array}$ \\
\hline 4 & $\begin{array}{l}\text { The members of the Management closely watch teachers. So, the } \\
\text { teachers are committed to duty. }\end{array}$ & $\begin{array}{l}\text { No monitoring of teaching is done. So, the teachers are } \\
\text { not committed to duty. }\end{array}$ \\
\hline 5 & $\begin{array}{l}\text { The teachers are under a heavy pressure to teach English } \\
\text { effectively. Owing to this pressure, they spontaneously and } \\
\text { continuously work hard and remain dedicated. }\end{array}$ & $\begin{array}{l}\text { The teachers' mode of functioning shows a lack of interest } \\
\text { and dedication. So, they are more complacent and are not } \\
\text { under pressure. Lack of proper monitoring of teaching is } \\
\text { the reason for some teachers not taking proper efforts in } \\
\text { carrying out their duty. }\end{array}$ \\
\hline 6 & $\begin{array}{l}\text { A good number of learners are given more chances to hone their } \\
\text { intelligence, abilities and skills. }\end{array}$ & $\begin{array}{l}\text { The learners are not given enough chances to hone their } \\
\text { intelligence, abilities, and skills. }\end{array}$ \\
\hline 7 & $\begin{array}{l}\text { A good number of learners are more blessed with all facilities } \\
\text { and favourable social, cultural, economic, educational and other } \\
\text { environmental factors. }\end{array}$ & $\begin{array}{l}\text { All the facilities and favourable social, cultural, economic, } \\
\text { educational and other environmental factors remain a } \\
\text { dream for majority of the learners. }\end{array}$ \\
\hline
\end{tabular}

\section{English Language Teaching Ambiance Which Prevails In The English Medium Schools} And In The Vernacular Medium Schools Is As Follows

\begin{tabular}{|c|l|l|}
\hline Points & \multicolumn{1}{|c|}{$\begin{array}{c}\text { English Language Teaching Ambiance in the English } \\
\text { Medium Schools }\end{array}$} & \multicolumn{1}{c|}{$\begin{array}{c}\text { English Language Teaching Ambiance in the } \\
\text { Vernacular Medium Schools }\end{array}$} \\
\hline 1 & $\begin{array}{l}\text { There are plenty of resources, infrastructures, and ambiance } \\
\text { available to learn English. }\end{array}$ & $\begin{array}{l}\text { Lack of resources, infrastructures, and ambiance to learn } \\
\text { English. }\end{array}$ \\
\hline 2 & $\begin{array}{l}\text { In spite of the absence of Sarva Shiksha Abian (Education For } \\
\text { language skills in English through activity-based learning. }\end{array}$ & $\begin{array}{l}\text { In spite of Sarva Shiksha Abian (Education For All) } \\
\text { Movement, and periodical in-service activity-based } \\
\text { training to the teachers, both the teachers and the learners } \\
\text { do not take efforts to hone their language skills in English. }\end{array}$ \\
\hline 3 & $\begin{array}{l}\text { In spite of the absence of several incentives and support schemes } \\
\text { by the State Government, the learners are interested to go to } \\
\text { school and the parents send their children to school because the } \\
\text { parents always look at the education of their children as a good } \\
\text { investment. }\end{array}$ & $\begin{array}{l}\text { In spite of several incentives and support schemes } \\
\text { launched by the State Government, the learners are not } \\
\text { interested to go to school and the parents are not interested } \\
\text { in sending their children to school because the parents } \\
\text { always look at their children as working hands who earn } \\
\text { extra income to their families. }\end{array}$ \\
\hline 4 & $\begin{array}{l}\text { There is plenty of peer-pressure for the children to hone their } \\
\text { language skills and knowledge and keep them in operational } \\
\text { efficiency. }\end{array}$ & $\begin{array}{l}\text { There is no peer-pressure for the children to hone their } \\
\text { language skills and knowledge and keep them in } \\
\text { operational efficiency. }\end{array}$ \\
\hline 5 & $\begin{array}{l}\text { The children are sent to school spontaneously. } \\
\text { and }\end{array}$ \\
\hline
\end{tabular}

\section{Special Features Of The English Medium Learners And The Vernacular Medium} Learners

\begin{tabular}{|l|l|l|}
\hline \multicolumn{1}{|c|}{ Points } & \multicolumn{1}{|c|}{ Features of the English Medium Learners } & \multicolumn{1}{c|}{ Features of the Vernacular Medium Learners } \\
\hline 1. & $\begin{array}{l}\text { The needs and priorities of the learners of English Medium are } \\
\text { different from the learners of Vernacular Medium. }\end{array}$ & $\begin{array}{l}\text { The needs and priorities of the learners of Vernacular } \\
\text { Medium are different from those of the learners of English } \\
\text { Medium. }\end{array}$ \\
\hline 2. & $\begin{array}{l}\text { The learners of English Medium are superior to the learners of } \\
\text { Vernacular Medium in terms of knowledge and ability. They } \\
\text { have knowledge and skills, which are better than those of the } \\
\text { learners of Vernacular Medium. }\end{array}$ & $\begin{array}{l}\text { The learners of Vernacular Medium are in no way inferior } \\
\text { to the learners of English Medium in terms of knowledge } \\
\text { and ability. Rather they are 'differently abled'. They have } \\
\text { knowledge and skills, which are neither better nor worse } \\
\text { than those of the learners of English Medium. }\end{array}$ \\
\hline 3. & $\begin{array}{l}\text { A large number of English Medium learners are often from } \\
\text { educated families. Therefore, they are able to get any support } \\
\text { from their family members in terms of material, knowledge, } \\
\text { skill, emotion and finance for education. }\end{array}$ & $\begin{array}{l}\text { A large number of Vernacular Medium learners are either } \\
\text { first or second generation learners. Therefore, they are } \\
\text { unable to get any support from their family members in } \\
\text { terms of material, knowledge, skill, emotion and finance for } \\
\text { education. }\end{array}$ \\
\hline
\end{tabular}




\section{Features Of The English Medium Teachers And The Vernacular Medium Teachers}

\begin{tabular}{|c|c|c|}
\hline Points & $\begin{array}{l}\text { Features of English Medium Teachers } \\
\end{array}$ & Features of Vernacular Medium Teachers \\
\hline 1 & $\begin{array}{l}\text { Though a few teachers are exceptions, majority of the teachers } \\
\text { are committed to duty and learners. Teaching English has } \\
\text { become a burden because they are either hired or fired based on } \\
\text { their efficiency or inefficiency to teach English effectively. They } \\
\text { do not enjoy the privilege of security of service. }\end{array}$ & $\begin{array}{l}\text { Apart from a few exceptions, majority of the teachers are } \\
\text { not committed to duty and learners. Teaching English has } \\
\text { not become a burden to them because they are neither } \\
\text { hired nor fired based on their efficiency or inefficiency to } \\
\text { teach English effectively. They do enjoy the privilege of } \\
\text { security of service. }\end{array}$ \\
\hline 2 & $\begin{array}{l}\text { Most teachers go to in-service training programmes with } \\
\text { 'learning mood'. They do have inclination to learn. }\end{array}$ & $\begin{array}{l}\text { Most teachers go to in-service training programmes with } \\
\text { 'picnic mood'. They do not have any inclination to learn. }\end{array}$ \\
\hline 3 & $\begin{array}{l}\text { The teachers have higher educational qualification and linguistic } \\
\text { competence compared to Vernacular Medium Teachers. }\end{array}$ & $\begin{array}{l}\text { The teachers have lower educational qualification and } \\
\text { linguistic competence compared to English Medium } \\
\text { Teachers (Amol 25[6]). }\end{array}$ \\
\hline 4 & $\begin{array}{l}\text { Most teachers' competence in English is higher than that of the } \\
\text { Vernacular Medium Teachers. They do take a lot of efforts on } \\
\text { their own to hone it and do make use of the in-service training } \\
\text { fully and seriously. }\end{array}$ & $\begin{array}{l}\text { Most teachers' competence in English is very low } \\
\text { compared to English Medium Teachers. Though they are } \\
\text { aware of it, they neither take any effort on their own to } \\
\text { hone it nor make use of the in-service training fully and } \\
\text { seriously. }\end{array}$ \\
\hline 5 & $\begin{array}{l}\text { There is a lot of peer-group pressure for them to develop their } \\
\text { knowledge and hone their language skills in English } \\
\text { continuously. }\end{array}$ & $\begin{array}{l}\text { There is no peer-group pressure for them to develop their } \\
\text { knowledge and hone their language skills in English } \\
\text { continuously. }\end{array}$ \\
\hline 6 & $\begin{array}{l}\text { They do not enjoy social prestige because of their low economic } \\
\text { status. But they enjoy high self-esteem because of their high } \\
\text { educational status. }\end{array}$ & $\begin{array}{l}\text { They enjoy social prestige because of their high economic } \\
\text { status. They suffer from low self-esteem because of their } \\
\text { low educational status (Amol } 25[6]) \text {. }\end{array}$ \\
\hline 7 & $\begin{array}{l}\text { Most teachers do not play out-of-the-school roles which are in no } \\
\text { way connected to their teaching profession. }\end{array}$ & $\begin{array}{l}\text { Most teachers play out-of-the-school roles which are in no } \\
\text { way connected to their teaching profession (Amol } 25[6]) \text {. }\end{array}$ \\
\hline
\end{tabular}

\section{Conclusion}

The conclusion from the above results is clear. There is a significant difference among the learners of the selected group of learners in learning writing skills in English. They constitute heterogeneous sub-groups.

In the prevailing language learning environment, there is significant difference between the learners of Government Schools which have the Vernacular as the Medium of Instruction and the learners of Private Schools which have English as the Medium of Instruction as for as the learning of paragraph writing skill in English is concerned.

Thus, the paper makes the readers understand and be aware of the status of ELT in rural Vernacular medium government schools and in urban English medium private schools. It makes the readers think aloud in this area chosen for research. It enables the readers to raise certain questions and to exhort the readers to carry out an in-depth research in this area, so that they would be able to find solutions or propose strategy to rectify the prevailing scenario and to teach English effectively in rural Vernacular medium government schools.

\section{Electronic Sources:}

\section{References}

[1] Johnson, Beverly. Teacher-As-Researcher. ERIC Digest. "Action research to improve school practice." New York: Teachers College, Columbia University. ERIC Clearinghouse on Teacher Education Washington DC. 1993. < http://www.ericdigests.org/1993/researcher.htm.>. 01 Aug. 2014.

[2] ERIC Digest. A Glossary of Measurement Terms. 1989. <http://ericae.net/edo/ed315430. htm>. 03 Aug. 2014.

Book:

[3] CIFEL. Methods of Teaching English. Blocks I \& II. Hyderabad: Latha, 1995. Print.

Thesis:

[4] Ambedkar, V. "Effectiveness of 'CAELL' in Teaching Grammar for Sixth Standard Students". M. Phil. Diss. Bhrathidasan Books: University, Tiruchirappalli, 1998. Print

[5] The Holy Bible: New King James Version. New York: Thomas Nelson, 1982. Print.

[6] Padwad, Amol. "Towards Understanding Rural ELT". Ed. Francis Peter. Indian Vioces in ELT. New Delhi: Viva, 2010. Print. 